Nigerian Journal of Physiological Sciences 23 (1-2): 13-17 @Physiological Society of Nigeria, 2008

Available online/abstracted at http://www.bioline.org.br/np; www.ajol.info/journals.njps; ww.cas.org

\title{
EFFECT OF ETHANOLIC EXTRACT OF DENNETTIA TRIPETALA FRUIT ON HAEMATOLOGICAL PARAMETERS IN ALBINO WISTAR RATS
}

\section{DANIEL E. IKPI and CLEMENT O. NKU}

\author{
Department of Physiology, College of Medical Sciences, University of Calabar, Calabar. Nigeria \\ E-mail: ikpidanielewa@yahoo.com
}

Summary: The effect of oral administration of ethanolic extract of Dennettia tripetala fruits on haematological parameters in albino Wistar rats was investigated. Lethality studies revealed that the extract had an $\mathrm{LD}_{50}$ value of $251.19 \mathrm{mg} / \mathrm{kg}$ mice intraperitoneal. Fifteen (15) male albino wistar rats weighing between $150-200 \mathrm{~g}$ were used for the study and randomly assigned into three study groups of five animals each. The group 1 control received via oral route a placebo ( $4 \mathrm{ml}$ of normal saline), while test groups 2 and 3 received $85 \mathrm{mg} / \mathrm{kg}$ body weight and $170 \mathrm{mg} / \mathrm{kg}$ body weight of $D$. tripetala extract in $2.0 \mathrm{ml}$ and $4.0 \mathrm{ml}$ of the vehicle (normal saline) via oral route respectively. The administration of ethanolic extract of $D$. tripetala for 14 days produced a significant $(\mathrm{P}<0.05)$ decrease in $\mathrm{RBC}$ and WBC counts in group 2 versus group 1 (control) but the decrease in RBC and WBC counts in group 3 were not significant compared to group 1. There was no significant difference in PCV and haemoglobin levels in groups 2 and 3 compared to control. The differential WBC results showed a significant increase $(\mathrm{P}<0.001)$ in neutrophil count in group 2 versus group 1 . While neutrophil count in group 3 was significantly decreased $(\mathrm{P}<0.001)$ compared to group 1 . There was a significant decrease $(\mathrm{P}<0.01)$ in eosinophil count in groups 2 and 3 when compared to the control group. From the results, there was a significant decrease $(\mathrm{P}<0.001)$ in lymphocyte count in group 2 while a significant increase $(\mathrm{P}<0.01)$ in lymphocyte count was observed in group 3 when compared to the control group. There were no significant differences in basophils and monocytes counts in groups 2 and 3 compared to the control group. The study shows that $D$. tripetala extract, given at moderate to high doses may have hematotoxic effect, but the effect was worse with moderate doses.

Key words: Dennettia tripetala, haematological indices, red blood cell, white blood cell

\section{Introduction}

Dennettia tripetala G. Baker

(Annonaceae) also known as pepper fruit tree is a well-known Nigerian spicy medicinal plant. It is found in the tropical rainforest region of Nigeria and sometimes in Savana areas (Okwu et al, 2005). It is locally called "Nkarika" by the Efiks of Calabar. The young leaves and fruits have instinctive spicy taste (Achinewhu et al, 1995). The mature fruits constitute the main edible portions. Some communities in parts of Southern Nigeria also utilized the leaves and roots, in addition to the fruits for medicinal purpose (Iwu, 1989). Dennettia triptala is used as masticators, which when chewed produces unique peppery effect (Keay, 1989). The peppery spicy taste of mature $D$. tripetala fruits usually serves as a mild stimulant to the consumer. The fruits are sometimes taken with kolanut, garden egg and palm wine in parts of Nigeria, especially in Southern part of Nigeria where it serves also for cultural entertainment of guests, particularly during coronation, new yam festivals, weddings and marriage festivals
(Enwere, 1998; Keay, 1989). Dennettia tripetala fruit has also been reported to be used as spice in flavouring food, and as seasoning which are added to prepared food such as meat, sausages, soups and vegetable (Lebouef and Caver, 1972). The peppery fruits of Dennettia tripetala are applied to the food meant for pregnant women and are important in the diets of postpartum women, during which time it is claimed that spices and herbs aid uterine contraction (Okwu and Morah, 2004; Achinewhu et al, 1995). Okwu et al (2005) also reported that D. tripetala fruits contain important nutritive substances such as vitamins, minerals and fibre.

Despite the extensive use of the fruit, much work has not been done to study some of the toxicological implications on other related systems. Motivated by this, the aim of the present study was to assess the effect(s) the ethanolic extract of $D$. tripetala fruits would have on some haematological parameters of the wistar rats. 


\begin{abstract}
Materials and Methods
Preparation of plant extract

Mature ripe fruits of Dennettia tripetala were obtained from the University of Calabar Botanical Garden and identified by Mr. Frank Apejoye, the Chief Herbarium Officer of Botany Department, University of Calabar, Calabar. The fruits were rinsed with water to remove debris and sand and then sun dried. The dry sample was milled with an electric blender and finally ground into powder. $110 \mathrm{~g}$ of the powdered plant sample was suspended in $660 \mathrm{mls}$ of ethanol $(98.67 \%, \mathrm{BDH}) \quad(80 \%$ $\mathrm{vol} / \mathrm{vol})$. The suspension was agitated with an electric blender for about 10 minutes then allowed in a refrigerator $\left(4^{\circ} \mathrm{C}\right)$. Twenty four hours later, the suspension was filtered with a chess cloth. The ethanolic filtrate was concentrated using a rotary evaporator at $40^{\circ} \mathrm{C}$. This concentrate was allowed in a water bath at $37^{\circ} \mathrm{C}$ for complete dryness, yielding $15.5 \mathrm{~g}$ (14.09\% yields) of crude extract. This was reconstituted to an appropriate concentration in distilled water prior to administration.
\end{abstract}

\section{Acute toxicity}

Seventy male albino wistar mice weighing $18-23 \mathrm{~g}$ were randomly assigned to seven (7) cages of 10 animals per cage. Each group respectively received the following doses: 100, 200, 400, 800, 1600,3200mg/kg body weight of the extract intraperitoneally (i.p). The maximum volume injected was $0.2 \mathrm{ml}$ and the control group received $0.2 \mathrm{ml}$ of normal saline i.p. The number of deaths in each group within 24 hours was recorded. The $\mathrm{LD}_{50}$ was estimated from the graph of percentage (\%) mortality (converted to probit) against $\log _{10}$ of the dose of the extract (Eno et $a l, 2001)$.

\section{Experimental design}

Fifteen male albino wistar rats weighing between $150-200 \mathrm{~g}$ were randomly assigned into three groups of 5 rats per group. They were maintained at room temperature of $30^{\circ} \mathrm{C}$ in the animal house of Physiology Department, Faculty of Basic Medical Sciences, University of Calabar, Calabar. The animals were fed with standard diet (product of Pfizer Nigeria, Ltd). There was free access to water. Group 1 served as control, groups 2 and 3 (extract treated groups) received orally the ethanolic extract of $D$. tripetala at doses of $85 \mathrm{mg} / \mathrm{kg}$ bwt and $170 \mathrm{mg} / \mathrm{kg}$ bwt respectively. After 14 days of extract administration, the animals from each group were sacrificed using chloroform anesthesia and blood obtained by cardiac puncture for analysis.

\section{Haematological estimations}

The blood samples collected into heparinized tubes were immediately used for determination of haematological parameters. Total red blood cell and white blood cell counts were estimated according to the visual method of Dacie and Lewis (1975). The percentage packed cell volume was determined according to the hematocrit method of Alexander and Griffiths (1993a) while the blood haemoglobin concentration in all samples were estimated according to the cyanomethaemoglobin method of Alexander and Griffiths (1993b).

\section{Differential White Blood Cell counts}

These were estimated using the method of Osim et al (2004). A dry micropipette was used to suck in blood from the blood sample bottle, a small drop of blood was applied to one end of a slide and quickly placed on the bench holding it in position, the end of the second slide was then placed in the drop and held there until the blood had spread across it. It was then drawn slowly over the whole length of the first slide being held at an angle of $45^{\circ}$. After the blood had spread, it was dried before staining with Leishman's stain. The film which was washed off in a gentle stream of water was dried with filter paper and examined under low and high power microscope and the different kinds of cells counted.

\section{Results}

Acute toxicity

Lethality studies showed that the crude ethanolic extract of $D$. tripetala fruits had an $\mathrm{LD}_{50}$ value of about $251.19 \mathrm{mg} / \mathrm{kg}$. mice, intraperitoneally (Fig. 1). From the results of the toxicity studies, convenient doses were chosen to preclude the lethal range.

Haematological indices

Table 1 shows haematological indices of rats following oral administration of ethanolic extracts of $D$. tripetala fruits for 14 days. There were decreases in RBC counts of rats in group $2\left(440.0 \times 10^{4} \pm 0.13 \times 10^{4}\right.$ cells per $\mathrm{mm}^{3}$ ) which received $85 \mathrm{mg} / \mathrm{kg}$ bwt of extract and group $3\left(487.2 \times 10^{4} \pm 0.15 \times 10^{4}\right.$ cells per $\mathrm{mm}^{3}$ ) which received $170 \mathrm{mg} / \mathrm{kg}$ bwt of extract. The decrease in RBC count of group 2 was significantly different $(\mathrm{P}<0.05)$ when compared to Group $1\left(510.0 \times 10^{4} \pm 0.18 \times 10^{4}\right.$ cells per $\mathrm{mm}^{3}$ of blood) which served as control group, while the RBC count in group 3 was significantly higher $(\mathrm{P}<0.05)$ than that of Group 2. 
Dennettia tripetala fruit and haematological parameters

Similarly, there was a decrease in WBC counts in groups 2 and 3 animals. However, the decrease was only significant $(\mathrm{P}<0.05)$ in Group $2\left(3.05 \times 10^{3} \pm 0.48 \times 10^{3} \pm 0.87 \times 10^{3}\right.$ cells per $\mathrm{mm}^{3}$ of blood) when compared to group $1\left(5.61 \times 10^{3} \pm 0.87 \times 10^{3}\right.$ cells per $\mathrm{mm}^{3}$ of blood). There was no significant difference in packed cell volume of rats in all the groups. The values were $34.99 \pm 1.40(\%)$ for group 1 , $33.40 \pm 1.63(\%)$ for group 2 and $35.40 \pm 0.93(\%)$ for group 3. Similarly, the blood haemoglobin concentration of group $2(12.26 \pm 1.02 \mathrm{~g} / \mathrm{dl})$ was lower when compared to group 1 (14.11 \pm $0.81 \mathrm{~g} / \mathrm{dl}$ ) while that of group 3 $(14.84 \pm 0.52 \mathrm{~g} / \mathrm{dl})$ was higher compared to group 1. However, the differences were not statistically significant $(\mathrm{P}>0.05)$.

Table 2 shows the differential WBC counts of rats gavaged with test doses of the ethanolic extract of $D$. tripetala. From the table, it is obvious that there was significant increase $(\mathrm{P}<0.001)$ in \% Neutrophil count in group $2(30.60 \pm 0.68)$ compared to group 1 $(22.80 \pm 1.07)$. However, the result for group $3(17.20 \pm 0.58)$ was significantly lower $(\mathrm{P}<0.001)$ compared to group 1 . There was a significant decrease $(\mathrm{P}<0.001)$ in $\%$ lymphocyte count in group 2 while a significant increase $\quad(\mathrm{P}<0.001)$ in $\%$ lymphocyte was observed in group 3 $(73.40 \pm 0.40)$ when compared to that of group

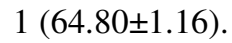

As shown in the table, there were no significant differences $(\mathrm{P}>0.01)$ in $\%$ Basophils and \% Monocytes in groups 2 and 3 compared to group 1. There was a significant decrease $(\mathrm{P}<0.01)$ in \% Eosinophil count in group $2(3.20 \pm 0.20)$ and group $3(3.20 \pm 0.20)$ when compared to group $1(4.60 \pm 0.24)$.

Table 1: Haematological indices of rats administered with ethanolic extract of D. tripetala fruits

\begin{tabular}{|c|c|c|c|c|c|}
\hline Group & Treatment & $\begin{array}{c}\text { RBC Count } \\
\text { per } \mathrm{mm}^{3} \text { blood } \\
\left(\mathrm{N} \times 10^{4} \text { cells }\right)\end{array}$ & $\begin{array}{c}\text { WBC count } \\
\text { per } \mathrm{mm}^{3} \text { of } \\
\text { blood }\left(N \times 10^{3}\right. \\
\text { cells })\end{array}$ & $P C V(\%)$ & $\begin{array}{c}\text { Hb Conc. } \\
(g / d l)\end{array}$ \\
\hline $\begin{array}{c}1 \\
\text { (control) }\end{array}$ & Normal saline & $510 \pm 0.18$ & $5.61 \pm 0.87$ & $34.99 \pm 1.40$ & $14.11 \pm 0.81$ \\
\hline 2 & $\begin{array}{c}\text { Extract } \\
(85 \mathrm{mg} / \mathrm{kg} \mathrm{bw})\end{array}$ & $440.0 \pm 0.13 *$ & $3.05 \pm 0.48^{*}$ & $33.40 \pm 1.63$ & $12.26 \pm 1.02$ \\
\hline 3 & $\begin{array}{c}\text { Extract } \\
(170 \mathrm{mg} / \mathrm{kg} \\
\text { bw })\end{array}$ & $487.0 \pm 0.15^{\mathrm{a}}$ & $4.59 \pm 0.91$ & $35.40 \pm 0.93$ & $14.84 \pm 0.52$ \\
\hline
\end{tabular}

Mean \pm SEM, $\mathrm{n}=5 * \mathrm{P}<0.05$, significant as compared with group 1 a $\mathrm{P}<0.05$ significant as compared with group 2

Table 2: Differential white blood cell count of Albino Wistar rats treated with ethanolic extract of D. tripetala fruit

\begin{tabular}{|c|c|c|c|c|c|c|}
\hline Group & Treatment & $\begin{array}{l}\text { Neutrophils } \\
(\%)\end{array}$ & $\begin{array}{l}\text { Lymphocytes } \\
(\%)\end{array}$ & $\begin{array}{l}\text { Basophils } \\
(\%)\end{array}$ & $\begin{array}{l}\text { Monocyte } \\
(\%)\end{array}$ & $\begin{array}{l}\text { Eosinophil } \\
(\%)\end{array}$ \\
\hline $\begin{array}{l}1 \\
\text { (control) }\end{array}$ & $\begin{array}{l}\text { Normal } \\
\text { saline }\end{array}$ & $22.80 \pm 1.07$ & $64.80 \pm 1.16$ & $0.40 \pm 0.24$ & $7.40 \pm 0.51$ & $4.60 \pm 0.24$ \\
\hline 2 & $\begin{array}{l}\text { Extract } \\
(85 \mathrm{mg} / \mathrm{kg} \\
\text { bwt })\end{array}$ & $\begin{array}{l}30.60 \pm \\
0.68 * * *\end{array}$ & $\begin{array}{l}59.60 \pm \\
1.03 * * *\end{array}$ & $0.40 \pm 0.24$ & $6.20 \pm 0.37$ & $3.20 \pm 0.24 * *$ \\
\hline 3 & $\begin{array}{l}\text { Extract } \\
(170 \mathrm{mg} / \mathrm{kg} \\
\text { bwt })\end{array}$ & $\begin{array}{l}17.20 \pm \\
0.58^{\mathrm{C}}\end{array}$ & $\begin{array}{l}73.40 \pm \\
0.40 * * *\end{array}$ & $3.20 \pm 0.20$ & $5.80 \pm 0.58$ & $3.20 \pm 0.20 * *$ \\
\hline
\end{tabular}

$* * * \mathrm{P}<0.001, * * \mathrm{P}<0.01$ significant as compared with group $1{ }^{\mathrm{c}} \mathrm{P}<0.01$ significant as compared with group 2.

\section{Discussion}

The effects of Dennettia tripetala fruit extract on the formed elements (erythrocytes, leucocytes, thrombocytes) of blood have not been documented. The present study was therefore aimed at evaluating the effects of ethanolic extract of $D$. tripetala fruits on haematological parameters viz - Rbc and Wbc counts, PCV, Hb concentration and differential WBC counts. The acute toxicity testing showed $\mathrm{LD}_{50}$ value of ethanolic crude extract of Dennettia tripetala fruit to be moderately high. 


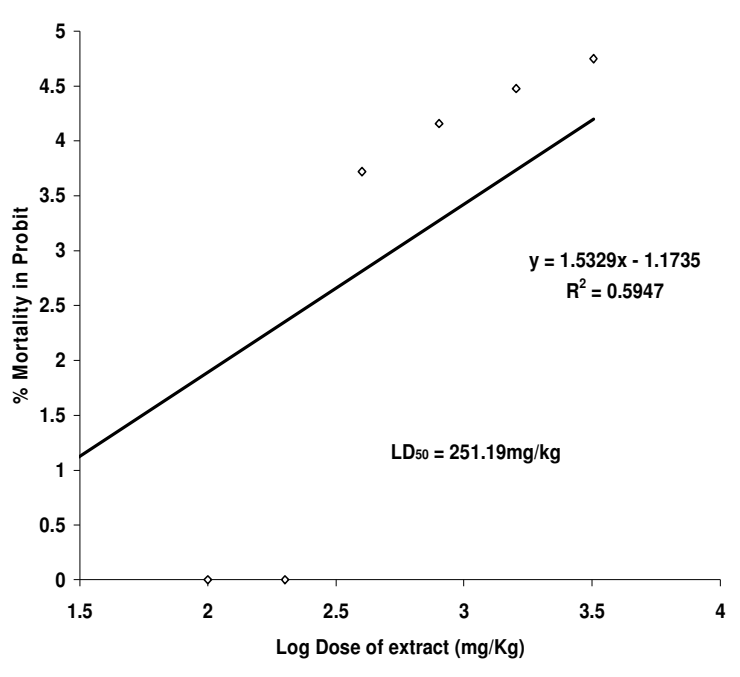

Fig. 1 Log dose probit curve showing percentage mortality for derivation of LD50 for $D$. tipetala, $\mathrm{n}=10$.

This suggests that the extract had a moderately high safety margin.

In this study, the RBC counts were significantly decreased in the group 2 rats and non-significantly decreased in the group 3 rats when compared to that of group 1 . However, the group 2 rats showed a significant decrease in WBC count when compared to the control while WBC count in group 3 was not significantly different from that of group 1 . However, PCV and blood $\mathrm{Hb}$ counts were not significantly different from that of group 1, although there was a slight non significant decrease in $\mathrm{Hb}$ and PCV counts in group 2 rats with respect to group 1 .

The observed decrease in RBC counts in D. tripetala treated groups may have been due to the suppressive effect of some components of the extract on bone marrow. These components such as alkaloids, saponins, flavonoids, tannins and phenols (Muller, 1980) may have suppressed the growth and differentiation factors in the bone marrow.

Another probable reason for the observed decrease in RBC counts may be due to hemolysis mediated via the phytochemical components of the extract, or may be the extract caused failure of erythropoietin production. This could lead to anemia. The slight nonsignificant increase in $\mathrm{Hb}$ concentration in group 3 which received a high dose of the extract may therefore result due to the increase in hemolysis of RBC.

It is well known that PCV otherwise called haematocrit represents the percentage of $\mathrm{RBC}$ in blood. There is a direct relationship between erythrocytes, PCV and haemoglobin concentration (Schalm et al, 1975) hence, an alteration in one parameter, alternately alters another. There was no significant change in PCV observed in this study, and this is not in agreement with the decrease in RBC count observed. The decrease in total WBC counts following oral administration of ethanolic extract of $\mathrm{D}$. tripetal is not in line with the normal physiological response following perception of a foreign attack by body defense mechanism. The decrease observed may have resulted from suppression of leucoytosis by the extract and also from the suppression of their production in the bone marrow.

However, there was a significant increase $(\mathrm{P}<0.001)$ in $\%$ Neutrophil count in group 2 $(30.60 \pm 0.68)$ compared to group 1 (22.80 \pm 1.07$)$, while there was a significant decrease $(\mathrm{P}<0.001)$ in \% neutrophil count in group 3 (17.20 \pm 0.58$)$ compared to group 2 . The observed increase in Neutrophil proliferation in group 2 which received a low dose of the extract may be related to the chemical composition of the extract, which later had a suppressing effect in group 3 rats that received a high dose of the extract.

There was a significant decrease $(\mathrm{P}<0.001)$ in \% lymphocytes in group 2 while a significant increase $(\mathrm{P}<0.001)$ in \% lymphocytes was observed in group 3 when compared to group 1 . The observed increase in lymphocyte proliferation in group 3 may also be related to the chemical composition of the extracts. Lymphocyte proliferation is a common parameter which has been measured in several studies investigating the immunomodulatory effects of metabolites (Gossage, 2000).

However, there was a significant decrease $(\mathrm{P}<0.01)$ in \% Eosinophil in groups 2 $(3.20 \pm 0.2)$ and $3(3.20 \pm 0.2)$ when compared to group $1(4.60 \pm 0.24)$. It may be that some component of the extract suppressed eosinophil proliferation.

\section{Conclusion}

Dennettia tripetala fruit is rich in minerals and vitamins (ascorbic acid, thiamine, riboflavin and niancin as documented by Okwu and Morah (2005). The study has shown the effect of ethanolic extract of $D$. tripetala on haematological parameters of wistar rats. It shows that $D$. tripetala extract, given at moderate to high doses may adversely affect haemotological parameters on account of its significant lowering effect on RBC and WBC counts. The effect was worse with moderate doses. Further studies to confirm this as well as evaluate its mechanism of action are suggested. 


\section{References}

Achinewhu, S. G., Ogbonna, C. and Hard, A. D. (1995). Chemical composition of indigenous wild herbs, spices fruits, nuts and leafy vegetables used as food. Plants Food for Human Nutrition. Kluwer Publishers, Netherlands. 48: $341-388$.

Alexander, R. R and Grifiths, J. M. (1993b). Haematocrit determination by the cyanomethaemoglobin method in: Biochemical Methods, $2^{\text {nd }}$ ed., John Wiley and Sons, Inc. Publications, New York, pp. $186-187$.

Dacie, J. V. and Lewis, S. M. (1975). Practical Haematology $5^{\text {th }}$ ed. Churchill Livingstone, London, pp. $502-503$.

Eno. A. E., Konya, R. S.; Ibu, J. O. (2001). Changes in blood pressure in the rats induced by the venom extract from a sea anemone - Burodosoma carvernata, Afri. $J$. Med. Sci. 30: 75 - 79.

Enwere, N. J. (1998). Foods of plant origin. Afro-Orbis Publications Ltd., University of Nigeria, Nsukka. Pp $169-180$.

Gossage, E. (2000). Effect of B-carotene supplementation and lactation on carotenoid metabolism and mitogenic Tlymphocyte proliferation. Am J. Clin. Nutri. 71: $950-955$.
Iwu, M. M. (1989). Food for medicine, in Dietary plants and masticastors as sources of biologically active substances. University of Ife Press. Pp. $303-310$.

Keay R W J. Trees of Nigeria, Clarendon Press Oxford, UK. 1989, Pp. $19-30$.

Lebouef, M and Caver, A. (1972). Alkaloids desecoces I; Uvariopsine guineensis. Phytochemistry 11: $28-33$.

Muller, H. G., Tobin, G. Nutrition and Food Processing, Groom Helm Ltd., London, UK. 1980.

Okwu, D. E. and Morah, F. N. I. (2004). Mineral and nutritive value of Dennettia tripetala fruits. Fruits 59: $437-442$.

Okwu, D. E., Morah, F. N. I. and Anam, E. M. (2005). Isolation and characterization of phenanthrenic alkaloid uvariopsine from Dennettia tripetala fruits. J. Med. Aromatic Plant Sci., 27: 496 - 498.

Osim, E. E., Akpogomeh, B. A., Ibu, J. O., Eno, A. E. (2004). Experimental Physiology Manual, Department of Physiology, University of Calabar, Calabar $3^{\text {rd }}$ ed. Pp. $60-81$.

Schalm, O. W., Jaivi, N. C. and Caroll, E. J. (1975). Veterinary Heamatology. $3^{\text {rd }}$ ed. Lea and Febiger, London. Pp $385-390$. 